was the first successful effort to take exact bird knowledge from the museum, and give it to the multitude, to place it within reach of all the world of those who love to hold our birds, not as skins, but as loving friends.

While birds were his main interest, he also collected other creatures. One of his prize finds was a rare western rattlesnake which he even stopped to collect while "under the untoward circumstances of a hasty retreat from hostile Indians". Although he often fought Indians, he eventually grew to champion them. While he saw what he considered defects or evils in their character, he concluded that

the Indian is neither a foreign power to be treated with, nor a wild beast to be hunted down, but a fellow-man to be reclaimed. Let us begin by calling him, that in the end we may make him, a brother.

Coues dabbled in theosophy and spiritualism. He became an exacting historian producing works on Lewis and Clark and other early western explorers, trappers and traders. But it is for his ornithological work that he will be remembered. His help to and influence upon Louis Agassiz Fuertes, undoubtedly America's greatest bird artist, is incalculable. And during his life Coues described 36 forms of bird and 18 forms of mammal new to science, many of them new genera and most of which are still recognized today.

Considering his intense and life-long love of birds, it is ironic that his most intense and persistent effort was an unrelenting war against one: the European house sparrow, recently introduced into North America. This particular bird he deeply loathed, and from the 1860 s onward attacked it and its defenders with equal venom. It is doubly ironic that the main defender and thus combatant was Coues' friend, T.M. Brewer. Brewer was not spared abuse even after his death - "We ... know that Brewer was a cantankerous old ass at the time he had the good taste to fall asleep in Jesus'. Nor was Coues' work ineffective; eventually he was even accused of "treason" due to having "incited a riot" against the sparrow. But he yielded to neither the bird nor its friends; in 1878 he publically divided the bird's defenders into five categories, four of them composed of idiots and the fifth of the weak-minded.

In the long term, of course, his efforts were in vain; the sparrow has spread in North America from coast to coast and from central Canada to southern Mexico. And the final irony? Coues certainly would not have been pleased when, in 1975, the American Ornithologists' Union presented their most prestigious recognition, the Elliott Coues Award, to a team of researchers for their notable study on the evolution of the house sparrow in North America.

\section{What's that (North American) animal?}

\section{Richard G. Van Gelder}

The Audubon Society Field Guide to North American Mammals. By John O. Whitaker, Jr. Pp.745. ISBN 0-39450762-2. (Knopf: 1981.) \$11.95. Harper \& Row's Complete Field Guide to North American Wildlife. Eastern Edition assembled by Henry Hill Collins, Jr. Pp.714. ISBN 0-690-01969-6. Western Edition assembled by Jay Ellis Ransom. Pp.809. ISBN 0-690-01971-8. (Harper \& Row: 1981.) \$12.95, £9.50 per volume.

THE purpose of a field guide is to enable one to identify an object without having that object in hand. This usually means that the criteria for identification are different from those on which the strict classification of the species is based. Nonetheless, some eminently successful field guides have been produced - birds, in particular, lend themselves to adequate field identification, to some extent because birds characterize themselves by sight and sound, two better-developed human senses. When it comes to animals with a greater dependence on odour or ultrasonics, such as shrews, rodents or bats, field identification becomes much more difficult. Despite the relative success of the "Peterson system" of field identification - drawings or paintings with "key" characteristics indicated, arranged for ready comparison - innovative attempts continue to be produced.

John O. Whitaker's Audubon Society Field Guide to North American Mammals is small enough to fit into a large pocket and is the first major attempt to utilize colour photographs for mammal identification. The 313 photographs (representing the 368 species, exclusive of whales and dolphins) are grouped rather sensibly by similar-sized and similarappearing species, even if unrelated; for instance muskrats, beavers and marmots appear together. While this may disconcert the taxonomist, it will probably aid the layman. The colour plates are followed by 403 pages of text dealing with each species, arranged in standard taxonomic order. These accounts include a description with italicized identifying characters and measurements, sign, breeding habits, habitat, range (with a small map) and excellent though concise life-history information. Marginalia often include drawings of animals not otherwise illustrated, and tracks. Appendices include a glossary and a complex "Range Chart" to

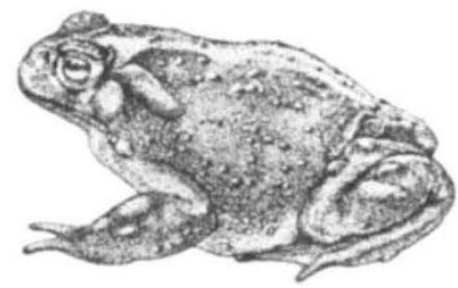

aid in the identification of some of the smaller mammals. The book is indexed and cross-referenced, but there is no bibliography.

Harper \& Row's Complete Field Guide to North American Wildlife attempts to provide notes on and a source for the identification of birds, mammals, reptiles, amphibians, fish, and molluscs and other marine invertebrates of America north of Mexico. The two volumes cover the eastern and western USA, divided at the 100th meridian. This involves considerable duplication of species accounts as well as of illustrations, but not necessarily of

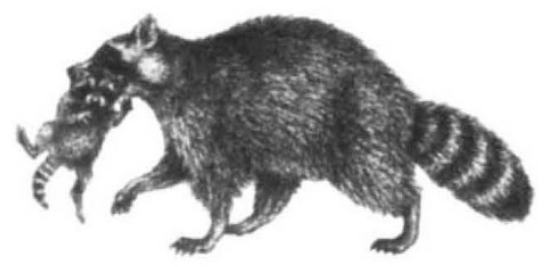

information - westerners are largely deprived of notes on the reproduction of mammals, for example. Within each species account there is a description, a comparison with similar species, and sadly variable and inconsistent information on habitat, habits, voice, food and range. Half of the total of 239 plates are in colour, and all are cross-referenced to the text (not always correctly or in the same volume), and "edge-marked". References are given in a section introducing each major taxonomic category.

Comparing the mammal sections, neither of these guides is superior for field identification to Burt and Grossenheider's volume, A Field Guide to the Mammals, in the "Peterson series", which has finer illustrations and maps. With Whitaker's book one is more likely to come up with a valid identification than with the Harper and Row volumes, but for most of the smaller species one has to resort to text descriptions and geographical information in both of these sources. Whitaker's small maps (without state or province boundaries) are useful, but the reader must be a good geographer to grasp the range of, for example, the Gray Myotis ("in se. U.S., from Ky., w. to Mo. and Kans., s. through Ala.") in a Harper and Row volume; the only map, on the inside of the front cover, does not identify the states.

For life-history information, Whitaker's book is the best single, concise source currently available, and for this reason is highly recommended. The larger Harper and Row volumes are a bit much for a pocket, and seem to have been planned by a committee to attract everyone, but satisfy noone. New York. 